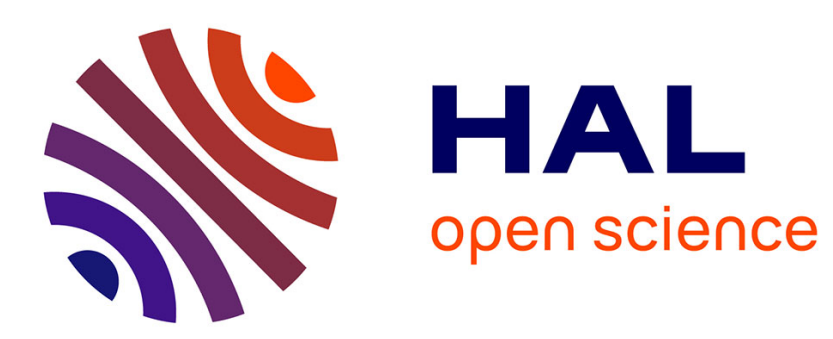

\title{
Seasonal variation of histopathological and histochemical markers of PAH exposure in blue mussel ( L.)
}

\author{
Nadia Aarab, Brit F. Godal, Renée K. Bechmann
}

\section{To cite this version:}

Nadia Aarab, Brit F. Godal, Renée K. Bechmann. Seasonal variation of histopathological and histochemical markers of PAH exposure in blue mussel ( L.). Marine Environmental Research, 2011, 71 (3), pp.213. 10.1016/j.marenvres.2011.01.005 . hal-00673197

\section{HAL Id: hal-00673197 https://hal.science/hal-00673197}

Submitted on 23 Feb 2012

HAL is a multi-disciplinary open access archive for the deposit and dissemination of scientific research documents, whether they are published or not. The documents may come from teaching and research institutions in France or abroad, or from public or private research centers.
L'archive ouverte pluridisciplinaire HAL, est destinée au dépôt et à la diffusion de documents scientifiques de niveau recherche, publiés ou non, émanant des établissements d'enseignement et de recherche français ou étrangers, des laboratoires publics ou privés. 


\section{Accepted Manuscript}

Title: Seasonal variation of histopathological and histochemical markers of PAH exposure in blue mussel (Mytilus edulis L.)

Authors: Nadia Aarab, Brit F. Godal, Renée K. Bechmann

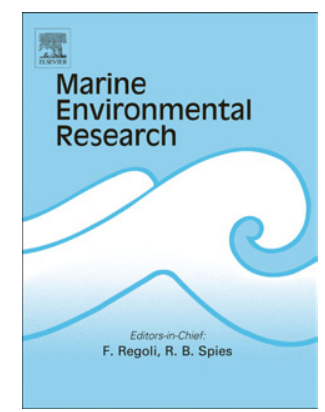

PII:

S0141-1136(11)00016-X

DOI:

10.1016/j.marenvres.2011.01.005

Reference: MERE 3501

To appear in: Marine Environmental Research

Received Date: 29 September 2010

Revised Date: 16 January 2011

Accepted Date: 20 January 2011

Please cite this article as: Aarab, N., Godal, B.F., Bechmann, R. Seasonal variation of histopathological and histochemical markers of PAH exposure in blue mussel (Mytilus edulis L.), Marine Environmental Research (2011), doi: 10.1016/j.marenvres.2011.01.005

This is a PDF file of an unedited manuscript that has been accepted for publication. As a service to our customers we are providing this early version of the manuscript. The manuscript will undergo copyediting, typesetting, and review of the resulting proof before it is published in its final form. Please note that during the production process errors may be discovered which could affect the content, and all legal disclaimers that apply to the journal pertain. 


\title{
ACCEPTED MANUSCRIPT
}

\section{Seasonal variation of histopathological and histochemical markers of \\ PAH exposure in blue mussel (Mytilus edulis L.)}

\author{
N. Aarab*, B.F. Godal and R.K.Bechmann \\ International Research Institute of Stavanger (IRIS), Mekjarvik 12 N-4070 Randaberg, Norway.
} 6

Abstract

The aim of this work was to study seasonal variation of histopathological and histochemical markers in blue mussels (Mytilus edulis L.) exposed to pyrogenic PAH contaminants. Mussels were collected in January 2007, June 2006 , September 2006 and October 2007 from a sampling site in the vicinity of the discharge from an aluminium smelter and from a clean reference site. Histopathological analysis was carried out on the digestive gland (DG) and the gonads. Lipofuscin and neutral lipids were analysed in the DG. Clear responses in lipofuscin and neutral lipids were detected in the DG of mussels collected from the polluted site at some sampling times. Moreover, these mussels presented atrophy in digestive tubules and haemocytic aggregates in the gonad and DG. However, in all parameters studied, the magnitude of the response showed clear seasonal variation.

0 Key words: Histopathology, neutral lipid, lipofuscin, PAH, Mytilus edulis, seasonal 21 variation.

* Corresponding author. Tel.:+47 51875066; fax +47 51875540. E-mail address: nadia.aarab@iris.no 
26

27

\section{Introduction}

Mussels are often used to evaluate the effect of contaminants in biomonitoring programs due to their ability to survive under polluted conditions and to accumulate both organic and metal pollutants (Lowe and Pipe, 1994; Moore, 1988; Viarengo, 1985). Biomarkers are often used to reflect the changes in cells and tissues caused by environmental contamination. Responses in such markers indicate that the organisms have been exposed to a pollutant (exposure biomarkers) and/or the magnitude of the organisms' response to the pollutant (biomarkers of effects). Histopathology is a biomarker of effects and may be used to identify pathological lesions in tissues induced by environmental contamination and disease. These changes reflect disturbances at the molecular level (Moore and Simpson, 1992) and can aid in the understanding of the overall health of the animals. Histopathology is often the easiest method for assessing both short- and long-term toxic effects in the field (Hinton and Laurèn, 1990) by providing an overall assessment of the general health status of mussels.

Lipofuscin (LF) and neutral lipid (NL) are biomarkers of effects often used in biomonitoring programs. NL is also considered as an exposure biomarker against organic chemical compounds (Marigomez and Baybay-Villacorta, 2003). These parameters are analysed in the digestive gland (DG) which can be affected by many pollutants (Axiak et al., 1988; Lowe, 1981; Lowe, 1988; Marigómez et al., 1986 ; Syasina et al., 1997; Tripp, 1984). The DG is the main site for metabolic activity; it is involved in immune defence, detoxification and in homeostatic regulation (Marigomez et al., 2002; Moore and Allen, 2002). The DG consists of many blind-ending tubules which are lined by a digestive epithelium, made up of digestive and basophilic cells. 
49 The lysosomes in the digestive cells have been identified as a target site for many

50 contaminants (Cajaraville et al., 1995; Moore, 1990).

$51 \mathrm{LF}$ is the end-product in the peroxidation process and is accumulated as insoluble

52 granules in the lysosomes. These granules consist of oxidatively modified proteins, lipid 53 degradation products, carbohydrates and metals (Terman and Brunk, 2004; Viarengo et 54 al., 2007), and the amount of accumulated granules indicates the oxidative stress levels 55 (Viarengo and Nott, 1993). This biomarker is influenced by seasonal temperature 56 changes and physiological processes such as the reproductive cycle (Bocchetti and 57 Regoli, 2006; Petrovic et al., 2004; Regoli, 1992). In addition, NL is a useful indicator 58 for the alterations of cell physiology (Koehler, 2004; Viarengo et al., 2007). The 59 accumulation of NL in lysosomes has been found to be a useful indicator of pollutant 60 exposed organisms (Moore, 1988).

61

62 In a previous paper, (Aarab et al., 2008) have reported that both LF and 63 histopathological examination of the DG, showed a strong response in mussels collected 64 from a pyrogenic PAHs polluted site. This present study is a following up of this work 65 and the aim was to investigate the seasonal variation of histopathological and

66 histochemical changes in mussels exposed to PAH contamination.

\section{2. Materials and Methods}

\section{$68 \quad 2.1$ Sampling}

69 Blue mussels, Mytilus edulis, were collected at two sites in the Southern part of Norway between June 2006 and October 2007. The water salinity in both sites ranges between 
72 (Høgevarde) is slightly north of the discharge from an old aluminium smelter in

73 Karmsund. The site had a production of about 200,000 tons of aluminium per year, and

74 the discharge of PAH to the Karmsund strait was approximately $450 \mathrm{~kg}$ annually

75 (Figure 4) (Beyer et al., 1998; Aarab et al., 2008). Previous results from mussels

76 collected in March and April 2006 are already published (Aarab et al., 2008). In this

77 follow-up paper we present results from mussels collected on four periods intended to

78 encompass seasonal variation. The mussels were sampled by scraping at $1 \mathrm{~m}$ depth the

79 following dates; 14. June 2006, 01. September 2006, 08. October 2007 and 16. January

80 2007. The number of mussels collected from each site varied between 15 to 30

81 specimens $(6.0 \mathrm{~cm} \pm 0.5 \mathrm{~cm})$.

\section{$82 \quad 2.2$ Histopathology}

83 During dissection, mussels were examined for the presence of parasites, pearls and other

84 tissue abnormalities. The gonads and DG were dissected and placed into individual

85 histocassettes, fixed in Baker's calcium solution (4\% formaldehyde, $1 \% \mathrm{CaCl}_{2}, 2,5 \%$

$86 \mathrm{NaCl}$ ) and dehydrated in alcohols. The tissues were cleared in methyl benzoate

$87\left(\mathrm{C}_{6} \mathrm{H}_{5} \mathrm{CO}_{2} \mathrm{CH}_{3}\right)$, rinsed in benzene $\left(\mathrm{C}_{6} \mathrm{H}_{6}\right)$ and embedded in paraffin. Histological

88 sections (5 $\mu \mathrm{m}$ thickness) were cut using a microtome HM 355s (Microm, Bergman),

89 mounted on slides, dried at $37^{\circ} \mathrm{C}$ for 24 hours and stained with hematoxylin and eosin.

90 The tissues were examined for health parameters related to reproductive and

91 physiological conditions, inflammatory and non-specific pathologies and those

92 associated with pathogen and parasite infections. The DG tubule atrophy was recorded

93 using a scoring index ranging from 0 to 3 (Brooks et al., 2009); 0: tubules nearly

94 occluded, slight atrophy in few tubules, 1: slight atrophy to one half normal tubule

95 thickness, 2: significant atrophy to one half tubule thickness and 3: extremely thin, most

96 tubules affected. The reproductive status was determined according to (Seed, 1976) as 
97 resting gonad (score 0), developing gonad (score 1-4), ripe gonad (score 5) or spawning gonad (score 1-4). The presence of parasites and non-specific inflammation were scored as absent (0) or present (1). 15 to 30 individuals were examined from each site, and 4

100 sections per individual were analyzed to score parasites, inflammation the tubule

101 atrophy. Micrographs were captured using an AxioCam MRc5 (Zeiss) digital camera

102 mounted on a Zeiss Axioplan 2 light microscope (Göttingen, Germany).

\section{2.3. Histochemistry}

104 Small pieces of freshly excised DG tissues were placed on metal cryostat chucks. Each 105 chuck was placed for less than $1 \mathrm{~min}$ in a pre-cooled $\left(-70^{\circ} \mathrm{C}\right)$ bath of $n$-hexane. The 106 metal chucks were then sealed by double-wrapping in parafilm and aluminum foil and 107 stored at $-40{ }^{\circ} \mathrm{C}$. Cryostat sections ( $8 \mu \mathrm{m}$ thickness) were cut in a cryostat Microm HM 108560 (Bergman) and transferred to slides $\left(20^{\circ} \mathrm{C}\right)$, and then stored at $-40{ }^{\circ} \mathrm{C}$ until use.

\subsubsection{Lipofuscin (LF)}

110 The accumulation of LF was determined using the Schmorl's reaction (Lowe, 1988).

111 The cryostat sections were fixed for $15 \mathrm{~min}$ in Baker's calcium solution at $4{ }^{\circ} \mathrm{C}$, rinsed

112 in distilled water and stained for $5 \mathrm{~min}$ in an aqueous solution of $1 \%$ ferric chloride, $1 \%$

113 potassium ferrocyanide and distilled water $\left[\left(\mathrm{FeCl}_{3}\right) /\left(\mathrm{K}_{4}\left[\mathrm{Fe}(\mathrm{CN})_{6}\right]\right) / \mathrm{H}_{2} \mathrm{O}\right.$ (7.5:1:1.5)].

114 The sections were rinsed in $1 \%$ acetic acid $\left(\mathrm{CH}_{3} \mathrm{COOH}\right)$ for 1 min and washed in

115 distilled water before mounting in an aqueous mounting medium.

\section{$116 \quad$ 2.3.2 Neutral lipid (NL)}

117 The determination of NL in digestive cells was carried out by the Oil red $\mathrm{O}$ method

118 (Bancroft, 1967). The cryostat sections were fixed for $15 \mathrm{~min}$ in Baker's calcium

119 solution at $4{ }^{\circ} \mathrm{C}$, rinsed in distilled water and transferred to a $60 \%$ solution of triethyl 120 phosphate $\left(\left(\mathrm{C}_{2} \mathrm{H}_{5}\right)_{3} \mathrm{PO}_{4}\right)$ for $5 \mathrm{~min}$. The sections were then stained with Oil Red $\mathrm{O}$ for 15 
121 min, rinsed in $60 \%$ triethyl phosphate, washed in distilled water and mounted in an

122 aqueous mounting medium.

\section{$123 \quad$ 2.3.3 Optical density assessment}

124 The average optical density of LF and NL were calculated from 2 micrographs per

125 individual (400x magnification) using a Zeiss Axioplan 2 light microscope (Carl Zeiss,

126 Göttingen, Germany) and the image analysis program AxioVision 4. Fifteen to thirty

127 individuals were examined from each site.

\section{$128 \quad 2.4$ Statistical analysis}

$129 \mathrm{JMP}^{\mathrm{R}}$ statistical computer software version 5.1 (SAS Institute, Cary, NC, USA) was

130 used to compare histopathological health parameters and the accumulation of LF and

131 NL between reference and polluted station. Analysis of variance (one way ANOVA)

132 and Control Dunnett's test were used to estimate significance. A significance level of

$133 P<0.05$ was applied in all statistical tests.

\section{3. Results}

\section{$136 \quad 3.1$ Histopathology}

\section{$137 \quad$ 3.1.1 Reproductive stage}

138 The median score of gonadal stage of mussels from site 1 was highest in January 2007

139 (4), followed by a decrease during June 2006 (3) and September 2006 (2), before

140 increasing again in October 2007 (3). The lowest maturation levels were recorded in

141 September 2006. The median gonadal stage of mussels from site 2 was highest in 
142 January 2007 and June 2006 (3), decreasing in September 2006 (1, 5) and October 2007

143 (1).

$144 \quad$ 3.1.2 Non-specific inflammation

145 Aggregations of haemocytes were found in gonadal follicles and digestive tubules in

146 mussels from both sites during this study (Figure 1). The observations were more

147 frequent in mussels collected from the polluted site (site 2) (55-95\%) during all

148 sampling periods, compared to mussels collected from reference site 1 (5- 50\%).

149 INSERT FIGURE 1

150

$151 \quad$ 3.1.3 Digestive gland pathology

152 Digestive tubule atrophy was observed in mussels from both sampling sites (Figure 3).

153 Mussels collected from site 2 were more severely affected than mussels collected from

154 site 1 in all sampling periods (Figure 2).

155 INSERT FIGURE 2

$156 \quad$ 3.1.4 Parasite infections

157 Three parasites were obseryed in mussels during the study: Marteilia sp., Steinhausia

158 mytilovum and digenean metacercaria (Figure 2). The number of mussels infected by

159 both Marteilia and digenean metacercaria at site 1 varied throughout the year, with the

160 lowest number of infected mussels in September 2006 (0-4\%). Mussels collected from

161 site 2 were highly infected in all sampling months (85-100\%). Steinhausia mytilovum

162 was only observed in the oocytes of 3 individuals from site 1 in June 2006. 
167 The accumulation of LF in mussels from both sites increased from January 2007 until

168 September 2006 and decreased in October. The accumulation of NL in mussels from

169 site 1 was low in January 2007, increasing in June 2006 and then decreasing in

170 September 2006 before reaching a maximum in October. The accumulation of NL in 171 mussels from site 2 was low in January 2007 and stable during September 2006 and

172 October 2007 (Table 1).

174 INSERT TABLE 1

\section{4. Discussion}

\section{$176 \quad 4.1$ Histopathology}

177 The high frequency of haemocytic aggregates observed inside the gonadal follicles and

178 DG tubules in mussels from the pyrogenic PAHs contaminated site might be due to the

179 presence of contaminants. This confirms results in an earlier study on mussels from the

180 same site (Aarab et al., 2008). Mussels exposed to a mixture of oil, PAHs and

181 alkylphenols also showed the same abnormalities in the gonads (Aarab et al., 2004).

182 Inflammatory reactions in the gonadal follicles have earlier been associated with

183 infections of Steinhausia mytilovum (Bignell et al., 2008). There were only three

184 Steinhausia-infected mussels in our study, so this may not explain the observed

185 inflammatory reactions. Haemocytic aggregates in the digestive tubules have been associated with infections of Marteilia sp. and digenean metacercaria (Bignell et al., 
187 2008). In our study, mussels from both sites were infected with these parasites and the

188 prevalence does not seem to agree with the number of mussels with an inflammatory

189 reaction.

190 The seasonal fluctuations in digestive tubule atrophy observed in reference mussels

191 have earlier been reported (Bignell et al., 2008). However, these fluctuations were not

192 observed in mussels collected from site 2. In addition to that, the same mussels present a

193 higher score than reference mussels. These observations may be explained by the

194 presence of PAH compounds (Moore and Clarke, 1982; Aarab et al., 2008). Infections

195 of Marteilia sp. may cause atrophy to digestive tubules (Bignell et al., 2008), but this

196 does not seem to be the case in the present study.

\section{$197 \quad 4.2$ Histochemistry}

198 The seasonal variation of accumulated LF in mussels from both reference and PAH 199 contaminated sites is probably due to a reduced metabolism in October 2007 and 200 January 2007 , caused by the effect of temperature and food availability (Bocchetti and

201 Regoli, 2006; Gorbi et al., 2008; Petrovic et al., 2004; Regoli, 1992). However, in June 2022006 and September 2006 the accumulation of LF in mussels from the polluted site was 203 higher than reference mussels. This might indicate a stress response to the 204 environmental conditions at this site. These results are in agreement with previous 205 studies that have reported that accumulation of LF is a very sensitive biomarker of stress 206 to PAHs (Da Ros et al., 2007; Pipe and Moore, 1986; Aarab et al., 2008), to industrial 207 and domestic waste water (Domouhtsidou and Dimitriadis, 2001; Petrovic et al., 2004) 208 and to heavy metals contamination (Krishnakumar et al., 1990; Krishnakumar et al., 209 1994; Regoli, 1992; Viarengo et al., 1987). 
210 The seasonal variation of NL accumulation seen in mussels collected from site 1 might

211 be explained by the reproductive cycle of the mussels. During the spawning season the

212 individuals move the NL from the DG to the gonad before spawning (Abad et al., 1995;

213 Cancio et al., 1999; Regoli et al., 1992; Thompson et al., 1974). Mussels collected from

214 the PAHs contaminated site did not seem to follow the same seasonal trend as the

215 reference mussels did, and they show a lower accumulation of NL in September 2006

216 and October. This low accumulation of NL might be caused by the environmental stress

217 since there was no difference in the gonadal stage in June 2006. Similar results in PAHs

218 and copper exposed mussels have earlier been observed (Zorita et al., 2006). Under

219 environmental stress mussels use their reserve materials from the DG during the

220 detoxification process (Regoli et al., 1992; Thompson et al., 1974). In agreement with

221 (Cancio et al., 1999) the low accumulation of NL in January 2007 is probably due to

222 the low food availability during this season.

223 One key issue raised from this study is that digestive tubule atrophy and haemocytic

224 aggregates in the DG can be used as an effect parameter for pyrogenic PAHs. However,

225 due to seasonal variation comparison of results between sites should relate to the same

226 sampling time during the year. Presence of such lesions may lead to misinterpretation of

227 NL accumulation, due to anatomical alterations in the cells.

228 Conclusion

229 In conclusion, the present study has demonstrated that lipofuscin and neutral lipids,

230 together with histopathological analysis of gonads and digestive gland are useful

231 parameters of stress caused by the pyrogenic PAHs. However, the seasonal variation,

232 combined with the health status and the reproductive stage of the organisms, needs to be

233 considered during interpretation. If these factors are taken into account, the 
234 histopathology and histochemistry are suitable tools to be used in PAHs environmental

235 monitoring programs. However, based on our results, we would recommend that

236 sampling for monitoring purposes should be carried out during the same months each

237 year, and that comparison between years should be based on results generated in the

238 same season (Garmendia et al., 2010). For more comprehensive programmes the

239 sampling schedule should reflect seasonal variation in the selection of sampling months.

\section{5. Acknowledgement}

241 This work was supported by the Research Council of Norway. The authors also wish to

242 thank Dr. D.M. Pampanin, A. Fiskå and L.P. Myhre for assistance during the field

243 work. We thank E. Lyng for assistance with the language.

\section{6. References}

245 Aarab, N., Minier, C., Lemaire, S., Unruh, E., Hansen, P.D., Larsen, B.K., Andersen,

246 O.K., Narbonne, J.F., 2004. Biochemical and histological responses in mussel (Mytilus

247 edulis) exposed to North Sea oil and to a mixture of North Sea oil and alkylphenols.

248 Marine Environmental Research 58, 437-441.

249 Aarab, N., Pampanin, D.M., Naevdal, A., Oysaed, K.B., Gastaldi, L., Bechmann, R.K., 250 2008. Histopathology alterations and histochemistry measurements in mussel, Mytilus 251 edulis collected offshore from an aluminium smelter industry (Norway). Marine 252 Pollution Bulletin 57, 569-574.

253 Abad, M., Ruiz, C., Martinez, D., Mosquera, G., Sanchez, J.L., 1995. Seasonal 254 variations of lipid classes and fatty-acids in flat oyster, Ostrea edulis, from San Cibran 255 (Galicia, Spain). Comparative Biochemistry and Physiology C-Pharmacology 256 Toxicology \& Endocrinology 110, 109-118.

257 Axiak, V., George, J.J., Moore, M.N., 1988. Petroleum hydrocarbons in the marine 258 bivalve Venus verrucosa: accumulation and cellular responses. Marine Biology 97, 225259230.

260 Bancroft, J.D., 1967. An introduction to histochemical techniques. Butterworths, 261 London.

262 Beyer, J., Aas, E., Borgenvik, H.K., Ravn, P., 1998. Bioavailability of PAH in effluent 
264 measurements of Atlantic cod (Gadus morhua L.). Marine Environmental Research 46, 265 233-236.

266 Bignell, J.P., Dodge, M.J., Feist, S.W., Lyons, B., Martin, P.D., Taylor, N.G.H., Stone,

267 D., Travalent, L., Stentiford, G.D., 2008. Mussel histopathology: and effects of season,

268 disease and species. Aquatic Biology 2, 1-15.

269 Bocchetti, R., Regoli, F., 2006. Seasonal variability of oxidative biomarkers, lysosomal 270 parameters, metallothioneins and peroxisomal enzymes in the Mediterranean mussel 271 Mytilus galloprovincialis from Adriatic Sea. Chemosphere 65, 913-921.

272 Brooks, S., Lyons, B., Goodsir, F., Bignell, J., Thain, J., 2009. Biomarker responses in 273 mussels, an integrated approach to biological effects measurements. Journal of 274 Toxicology and Environmental Health-Part a-Current Issues 72, 196-208.

275 Cajaraville, M.P., Abascal, I., Etxeberria, M., Marigomez, I., 1995. Lysosomes as 276 cellular markers of environmental pollution: time dependent and dose dependent 277 responses of the digestive lysosomal system of mussels after petroleum hydrocarbon 278 exposure. Environmental Toxicology and Water Quality 10, 1-8.

279 Cancio, I., Ibabe, A., Cajaraville, M.P., 1999. Seasonal variation of peroxisomal enzyme 280 activities and peroxisomal structure in mussels Mytilus galloprovincialis and its 281 relationship with the lipid content. Comparative Biochemistry and Physiology C282 Toxicology \& Pharmacology 123, 135-144.

283 Da Ros, L., Moschino, V., Guerzoni, S., Halldorsson, H.P., 2007. Lysosomal responses 284 and metallothionein induction in the blue mussel Mytilus edulis from the south-west coast of Iceland. Environment International 33, 362-369.

286 Domouhtsidou, G.P., Dimitriadis, V.K., 2001. Lysosomal and lipid alterations in the 287 digestive gland of mussels, Mytilus galloprovincialis (L.) as biomarkers of 288 environmental stress. Environmental Pollution 115, 123-137.

289 Garmendia, L., Soto, M., Cajaraville, M.P., Marigomez, I., 2010. Seasonality in cell and 290 tissue-level biomarkers in Mytilus galloprovincialis: relevance for long-term pollution 291 monitoring. Aquatic Biology 9, 203-219.

292 Gorbi, S., Lamberti, C.V., Notti, A., Benedetti, M., Fattorini, D., Moltedo, G., Regoli, 293 F., 2008. An ecotoxicological protocol with caged mussels, Mytilus galloprovincialis, 294 for monitoring the impact of an offshore platform in the Adriatic sea. Marine 295 Environmental Research 65, 34-49.

296 Hinton, D.E., Laurèn, D.J., 1990. Integrative histopathological effects of environmental 297 stressors on fishes. American Fisheries Society Symposium 8, 51-66.

298 Koehler, A., 2004. Toxic injury and gender-specific hepatocellular carsinogenesis in 299 flounder (Platichthys flesus (L.)). Aquatic Toxicology 70, 257-276. 
300 Krishnakumar, P.K., Asokan, P.K., Pillai, V.K., 1990. Physiological and cellular 301 responses to copper and mercury in the green mussel Perna Viridis (Linnaeus). Aquatic

302 Toxicology 18, 163-173.

303 Krishnakumar, P.K., Casillas, E., Varanasi, U., 1994. Effect of environmental 304 contaminants on the health of Mytilus edulis from Puget Sound, Washington, USA .1. 305 Cytochemical measures of lysosomal responses in the digestive cells using automatic 306 image-analysis. Marine Ecology Progress Series 106, 249-261.

307 Lowe, D.M., 1988. Alterations in cellular structure of Mytilus edulis resulting from 308 exposure to environmental contaminants under field and experimental conditions. 309 Marine Ecology Progress Series 46, 91-100.

310 Lowe, D.M., Moore, M.N., Clarke, K.R., 1981. Effect of oil on digestive cells in 311 mussels: quantitative alterations in cellular and lysosomal structure. Aquatic Toxicology 312 1, 213-226.

313 Lowe, D.M., Pipe, R.K., 1994. Contaminant induced lysosomal membrane damage in marine mussel digestive cells an in-Vitro study. Aquatic Toxicology 30, 357-365.

315 Marigomez, I., Baybay-Villacorta, L., 2003. Pollutant-specific and general lysosomal 316 responses in digestive cells of mussels exposed to model organic chemicals. Aquatic 317 Toxicology 64, 235-257.

318 Marigomez, I., Soto, M., Cajaraville, M.P., Angulo, E., Giamberini, L., 2002. Cellular 319 and subcellular distribution of metals in molluscs. Microscopy Research and Technique. $320 \quad 56,358-392$.

321 Marigómez, J.A., Angulo, E., Moya, J., 1986. Copper treatment of the digestive gland 322 of the slug Arion ater L. 2. Morphometrics and histophysiology Bulletin of 323 Environmental Contamination and Toxicology 36, 608-615.

324 Moore, M.N., 1988. Cytochemical responses of the lysosomal system and NADPH325 ferrihemoprotein reductase in molluscan digestive cells to environmental and 326 experimental exposure to xenobiotics. Marine Ecology Progress Series 46, 81-89.

327 Moore, M.N., 1990. Lysosomal cytochemistry in marine environmental monitoring. 328 Histochemical Journal 22, 187-191.

329 Moore, M.N., Allen, J.I., 2002. A computational model of the digestive gland epithelial 330 cell of marine mussels and its simulated responses to oil-derived aromatic 331 hydrocarbons. Marine Environmental Research 54, 579-584.

332 Moore, M.N., Clarke, K.R., 1982. Use of microstereology and quantitative 333 cytochemistry to determine the effects of crude oil-derived aromatic hydrocarbons on 334 lysosomal structure and function in a marine bivalve mollusc, Mytilus edulis. 335 Histochemical Journal 14, 713-718.

336 Moore, M.N., Simpson, M.G., 1992. Molecular and cellular pathology in environmental 337 impact assessment. Aquatic Toxicology 22, 313-322. 
338 Petrovic, S., Semencic, L., Ozretic, B., Ozretic, M., 2004. Seasonal variations of 339 physiological and cellular biomarkers and their use in the biomonitoring of north

340 Adriatic coastal waters (Croatia). Marine Pollution Bulletin 49, 713-720.

341 Pipe, R.K., Moore, M.N., 1986. An ultrastructural effect of phenanthrene on lysosomal

342 membranes and distribution of the lysosomal beta-glucoronidase in digestive cells of the

343 periwinkle Littorina littorea. Aquatic Toxicology 8, 65-76.

344 Regoli, F., 1992. Lysosomal responses as a sensitive stress index in biomonitoring 345 heavy-metal pollution. Marine. Ecology.-Progress. Ser. 84, 63-69.

346 Regoli, F., Nigro, M., Orlando, E., 1992. Effects of copper and cadmium on the 347 presence of renal concretions in the bivalve Donacilla cornea. Comparative 348 Biochemistry and Physiology C-Pharmacology Toxicology \& Endocrinology 102, 189349192.

350 Seed, R., 1976. Ecology. Marine mussels, their ecology and physiology, in: Bayne, B.L. 351 (Ed.), International Biological Programme 10. Cambridge University Press, Cambridge, 352 pp. 13-65.

353 Syasina, I.G., Vaschenko, M.A., Zhadan, P.M., 1997. Morphological alterations in the 354 digestive diverticula of Mizuhopecten yessoensis (Bivalvia: Pectinidae) from polluted 355 areas of Peter the Great Bay, Sea of Japan. Marine Environmental Research 44, 85-98.

356 Terman, A., Brunk, U.T., 2004. Lipofuscin. International Journal of Biochemistry and 357 Cellular Biology. 36, 1400-1404.

358 Thompson, R.J., Ratcliffe, N.A., Bayne, B.L., 1974. Effects of starvation on structure 359 and function in the digestive gland of the mussel (Mytilus edulis L.). Marine Biology 360 Association UK 54, 699-712.

361 Tripp, M.R., Fries, C. R., Craven, M. A., Grier, C. E., 1984. Histopathology of 362 Mercenaria mercenaria as an indicator of pollutant stress. Marine Environmental 363 Research 14, 521-524.

364 Viarengo, A., 1985. Biochemical effects of trace metals. Marine Pollution Bulletin 16, $365 \quad 153-158$.

366 Viarengo, A., Lowe, D., Bolognesi, C., Fabbri, E., Koehler, A., 2007. The use of 367 biomarkers in biomonitoring: A 2-tier approach assessing the level of pollutant-induced 368 stress syndrome in sentinel organisms. Comparative Biochemistry and Physiology C369 Toxicology \& Pharmacology 146, 281-300.

370 Viarengo, A., Moore, M.N., Mancinelli, G., Mazzucotelli, A., Pipe, R.K., Farrar, S.V., 371 1987. Metallothioneins and lysosomes in metal toxicity and accumulation in marine 372 mussels - the effect of cadmium in the presence and absence of phenanthrene. Marine 373 Biology 94, 251-257. 
374 Viarengo, A., Nott, J.A., 1993. Mechanisms of heavy metal cation homeostasis in 375 marine invertebrates. Comparative Biochemistry and Physiology C-Pharmacology 376 Toxicology \& Endocrinology 104, 355-372.

377 Zorita, I., Ortiz-Zarragoitia, M., Soto, M., Cajaraville, M.P., 2006. Biomarker responses 378 in mussels transplanted to a copper site gradient (Visnes, Norway). Marine 379 Environmental Research 62, S398-S398.

380

381 


\section{Research Highlights}

- The present study has demonstrated that lipofuscin and neutral lipids, together with histopathological analysis of gonads and digestive gland are useful biomarkers of stress caused by the pyrogenic PAHs.

- For more comprehensive biomonitoring programmes the sampling schedule should reflect seasonal variation in the selection of sampling months ( reproduction cycle).

- The seasonal variation, combined with the health status and the reproductive stage of the organisms, needs to be considered during interpretation.

- The histopathology and histochemistry are suitable tools to be used in PAHs environmental monitoring programs. 
Table1. Optical density measurements recorded for lipofuscin and neutral lipids in mussels collected from reference site (site 1) and PAHs contaminated site (site 2).* $p=2.10^{-4}$, ** $p=2.10^{-8}$.

Figure1. Prevalence of non-specific inflammation, HA: Hemocytic aggregates in gonads and digestive gland (DG) of mussels collected from reference site (site 1) and PAHs contaminated site (site 2) during all sampling dates.

Figure2. Histological sections through the digestive gland and gonad of Mytilus edulis (a-d). (a) Digestive gland with a digenean metacercaria (arrow head) and digestive tubules (arrows) in a mussel collected from site 1. (b) Digestive gland with atrophic tubules (arrows) in mussel collected from site 2. (c) Hemocytic aggregates (arrows) within the testicular follicle in mussel from site 1. (d) Melanised hemocytic aggregate (arrow) within the testicular follicle and hemocytic aggregate in connective tissue (arrow head) in mussel from site 2. Hematoxylin and eosin (H\&E) staining. Section: $5 \mu \mathrm{m}$ thickness. Scale bare is given in lower right corner of the panel.

Figure3. Average score of digestive tubule atrophy in mussels collected from the reference site (site 1) and PAHs contaminated site (site 2 ) during all sampling dates. * $p=1,3.10^{-2}, * * p=8.10^{-7}$.

Figure4. US EPA PAHs (in $\mathrm{mg} / \mathrm{kg}$ wet weight given as average of six pools of 10 individuals from each locality) and st dev. The exposed locality Høgevarde (site 2) is showing a pyrogenic PAH profile whereas levels in the reference locality Førlandsfjorden (site 1) represents natural background levels (Aarab et al., 2008). 


\begin{tabular}{|c|c|c|c|c|c|}
\hline & & \multicolumn{4}{|c|}{ Sampling months } \\
\hline & & January & June & September & October \\
\hline \multirow{2}{*}{ 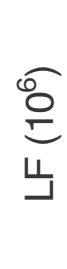 } & Site 1 & 4.0 & 7.8 & 24.6 & 14.1 \\
\hline & Site 2 & 2.6 & $\begin{array}{c}\star \star \\
27.4\end{array}$ & 31.2 & 12.8 \\
\hline \multirow{2}{*}{ 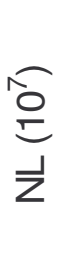 } & Site 1 & 1.2 & 8.1 & 6 & 10.5 \\
\hline & Site 2 & 2.2 & $\begin{array}{c}\star \\
4.8\end{array}$ & 4.7 & $\begin{array}{l}* * \\
5.1\end{array}$ \\
\hline & & & & & \\
\hline
\end{tabular}

Table1. 


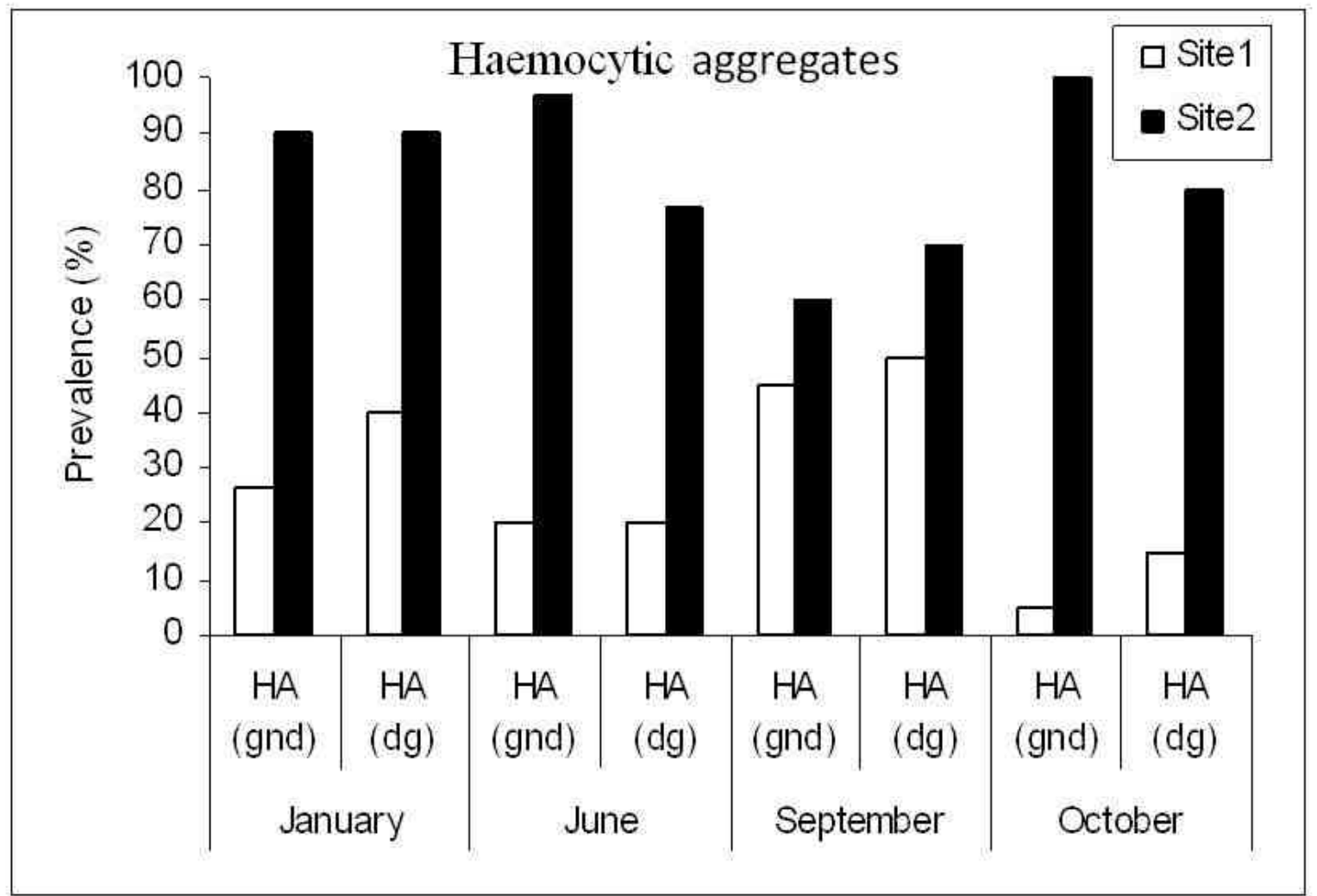

Figure1. 

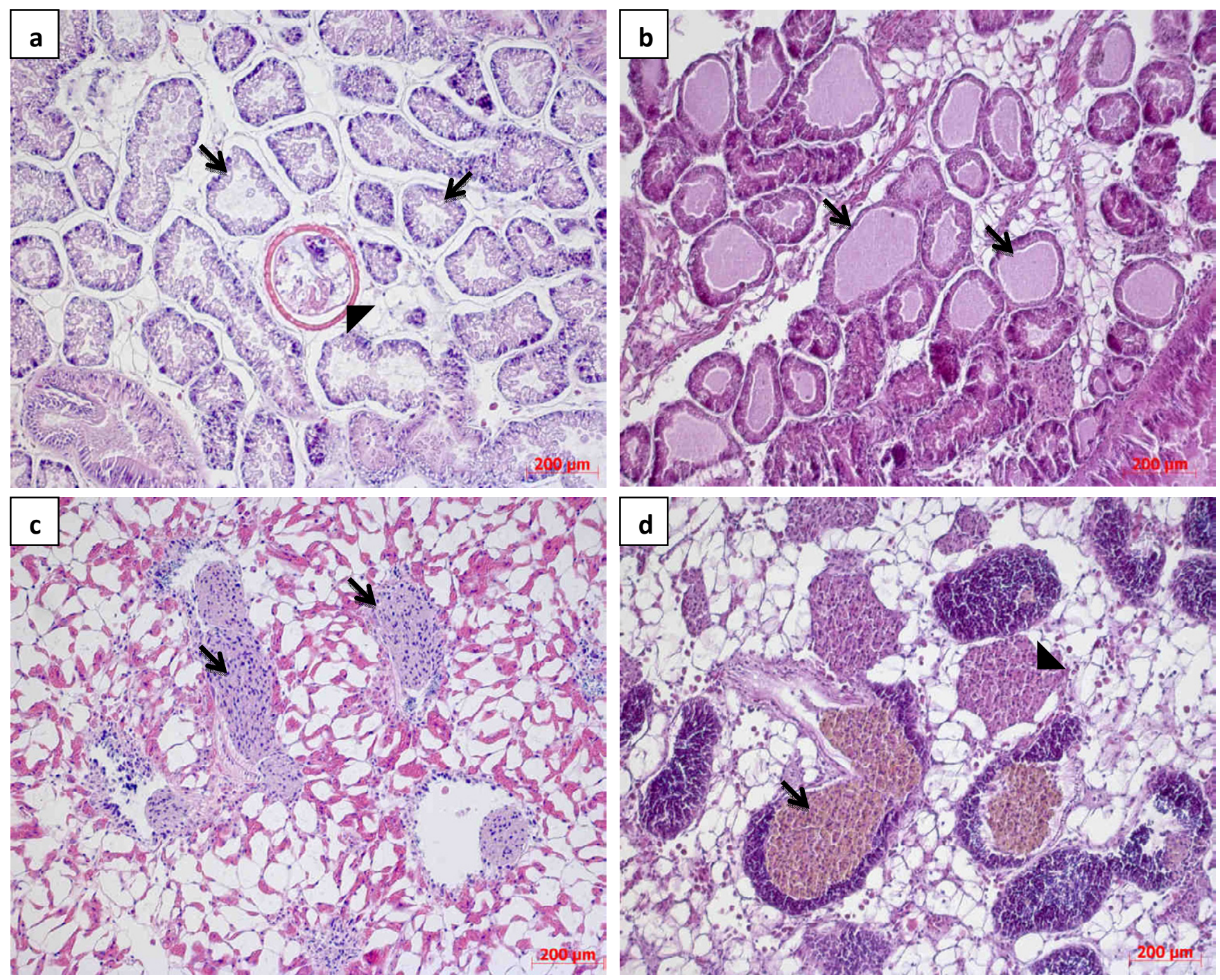

Figure 2 


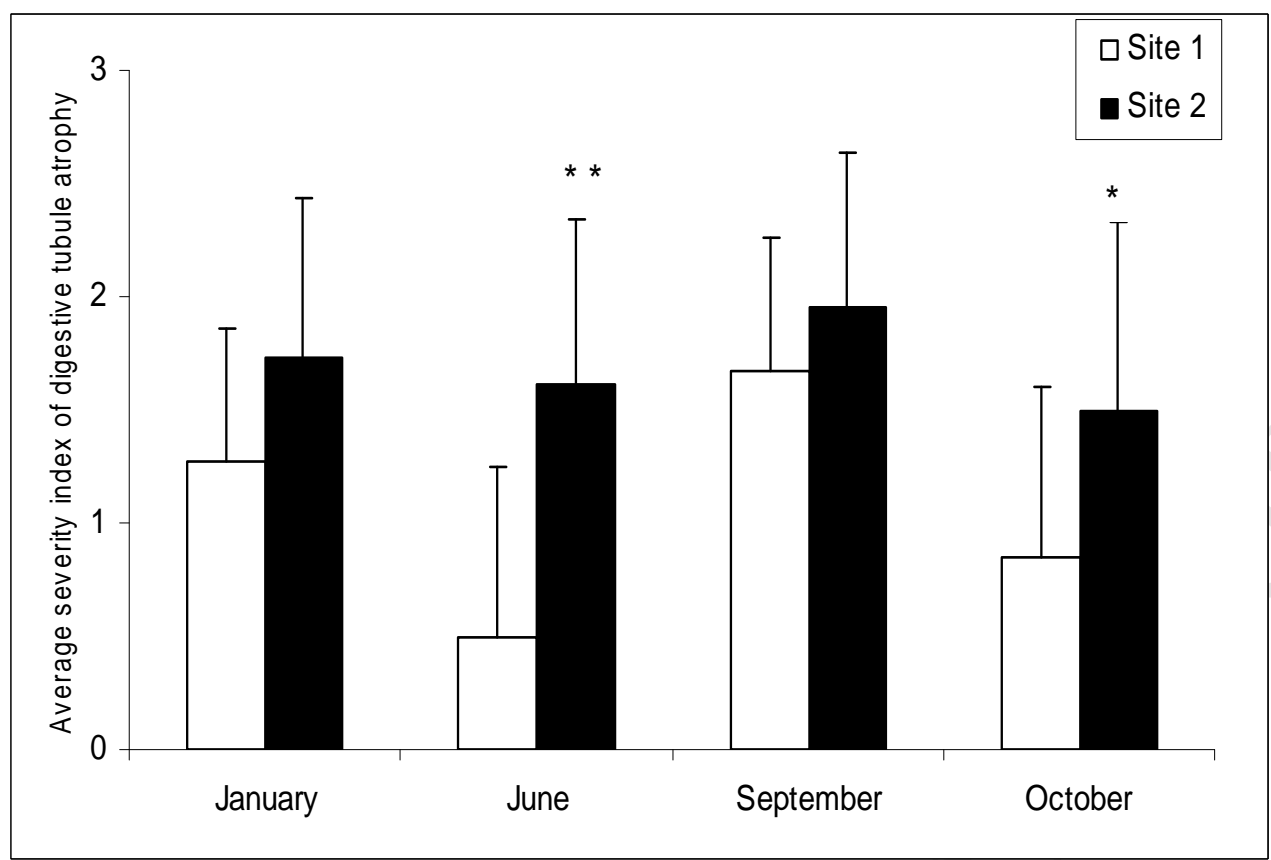

Figure3. 


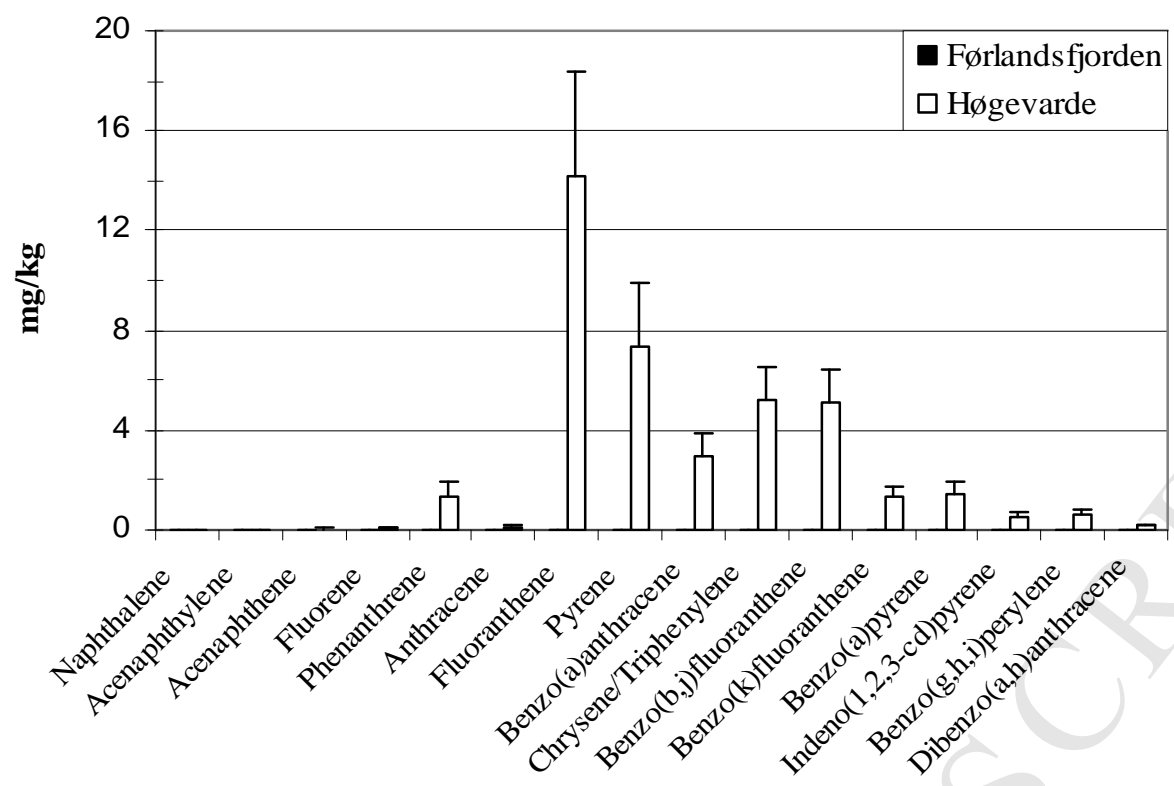

Figure 4. US EPA PAHs (in $\mathrm{mg} / \mathrm{kg}$ wet weight given as average of six pools of 10 individuals from each locality) and st dev. The exposed locality Høgevarde is showing a pyrogenic PAH profile whereas levels in the reference locality Førlandsfjorden represents natural background levels. (Aarab et al., 2008) 